\title{
Analisis Inovasi Kebijakan Daerah dalam Rangka Pengurangan Kesenjangan Wilayah
}

\author{
Fajar Sumirat ${ }^{1}$ \\ Kementerian Perencanaan Pembangunan Nasional/Bappenas - Indonesia
}

\begin{abstract}
Abstraksi:
Kesenjangan wilayah di Indonesia dipandang relatif masih cukup tinggi, khususnya kesenjangan pembangunan antara Kawasan Barat Indonesia dan Kawasan Timur Indonesia. Di samping itu juga terdapat kesenjangan antara wilayah desa dan kota. Kesenjangan pembangunan antara desa-kota maupun antara kota-kota perlu ditangani secara serius untuk mencegah terjadinya urbanisasi, yang pada gilirannya akan memberikan beban dan masalah sosial di wilayah perkotaan. Pada dasarnya kesenjangan pembangunan antarwilayah merupakan aspek yang umum terjadi dalam kegiatan ekonomi suatu wilayah. Terjadinya ketimpangan antarwilayah ini berimplikasi terhadap tingkat kesejahteraan masyarakat antarwilayah, yang dapat mengganggu stabilitas keamanan negara akibat kecemburuan masyarakat terutama yang berasal dari daerah dengan tingkat kesejahteraan lebih rendah. Pelaksanaan otonomi daerah pada dasarnya bertujuan agar daerah terdorong untuk kreatif dalam mengelola sumber daya yang dimilikinya dalam melakukan pembangunan sesuai dengan kebutuhan dan karakteristik masingmasing daerah. Bila hal ini dapat dilakukan, maka proses pembangunan daerah secara keseluruhan akan dapat lebih ditingkatkan dan secara bersamaan ketimpangan pembangunan antar wilayah dapat pula dikurangi.
\end{abstract}

Kata Kunci: kesenjangan wilayah, perkotaan, perdesaan, kesejahteraan masyarakat, pembangunan wilayah, inovasi.

${ }^{1}$ Fajar Sumirat adalah Perencana Muda di Pusat Analisis Kebijakan, Kementerian PPN/Bappenas Republik Indonesia. E-mail: fajar.sumiratbappenas@yahoo.com 


\title{
Analisis Inovasi Kebijakan Daerah dalam Rangka Pengurangan Kesenjangan Wilayah
}

\author{
Fajar Sumirat
}

\section{Latar Belakang}

\subsection{Kesenjangan Wilayah di Indonesia}

Berdasarkan definisi OECD (2003), kesenjangan wilayah (regional disparities) menggambarkan perbedaan intensitas yang dimanifestasikan melalui fenomena ekonomi yang diamati pada sejumlah wilayah dalam satu negara. ILO (2002) menyebutkan bahwa kesenjangan wilayah adalah perbedaan performa ekonomi dan kesejahteraan antarwilayah. Peneliti lain (Gajdos, 2006) menyebutkan bahwa kesenjangan wilayah adalah perbedaan atau ketidaksamaan karakteristik, fenomena atau kondisi lokasi dan terjadi minimal di antara dua entitas dari struktur wilayah. Oleh karena itu, seyogyanya ketimpangan harus dinilai dari berbagai aspek seperti sosial, kondisi lokasi, politik dan administrasi, kelembagaan, lingkungan, infrastruktur umum, dan lain-lain.

Kesenjangan wilayah di Indonesia dipandang relatif masih cukup tinggi, khususnya kesenjangan pembangunan antara Kawasan Barat Indonesia (KBI) dan Kawasan Timur Indonesia (KTI). Selama 30 tahun (1986-2016) kontribusi Produk Domestik Regional Bruto (PDRB) KBI sangat dominan dan tidak pernah kurang dari $80 \%$ terhadap PDB. Sampai dengan Triwulan I tahun 2019, Pulau Jawa dan Sumatera masih menjadi kontributor utama bagi perekonomian nasional $(80,39 \%)^{2}$. Kesenjangan antarwilayah juga dapat dilihat dari masih adanya 122 kabupaten $( \pm$ $24 \%$ dari jumlah kabupaten/kota di Indonesia) yang merupakan daerah tertinggal. Ada beberapa kebijakan yang dikembangkan untuk meningkatkan kontribusi wilayah-wilayah lain di luar Jawa dan Sumatera terhadap perekonomian nasional, diantaranya adalah mengembangkan dan memeratakan pembangunan daerah melalui peningkatan kinerja pusat-pusat pertumbuhan wilayah di Kalimantan, Sulawesi, Nusa Tenggara, Maluku dan Papua; menjamin pemenuhan pelayanan dasar di seluruh wilayah; mempercepat pembangunan daerah tertinggal dan kawasan perbatasan; serta mengoptimalkan pelaksanaan desentralisasi dan otonomi daerah.

Isu kesenjangan wilayah ini juga terkait dengan isu pemerataan pembangunan, dimana isu pemerataan pembangunan menjadi suatu keniscayaan bila kita cermati komparasinya dengan perkembangan kawasan regional, melalui peringkat indeks pembangunan inklusif atau Inclusive Development Index (IDI), yang dirilis World Economic Forum (WEF) tahun 2018. Dari 77 negara berkembang, Indonesia menempati peringkat ke-36 indeks pemerataan pembangunan, di bawah Thailand dan Malaysia, yang masing-masing menempati posisi 17 dan 13. Secara umum, perkembangan tingkat kesenjangan antarwilayah di Indonesia dapat dilihat dari nilai Gini Rasio. Pada dasarnya kesenjangan pembangunan antarwilayah merupakan aspek yang umum terjadi dalam kegiatan ekonomi suatu wilayah. Ketimpangan disebabkan oleh adanya perbedaan potensi sumber daya alam dan perbedaan kondisi geografi yang terdapat pada masing-masing wilayah. Akibat dari perbedaan ini, kemampuan suatu daerah dalam mendorong proses pembangunan juga menjadi berbeda-beda. Selain itu juga dapat terjadi akibat adanya perbedaan

${ }^{2}$ Badan Pusat Statistik, TW I 2019; 
kondisi demografis, kurang lancarnya arus mobilitas barang dan jasa, konsentrasi ekonomi kegiatan wilayah, serta alokasi dana pembangunan antar wilayah. Terjadinya ketimpangan antarwilayah ini berimplikasi terhadap tingkat kesejahteraan masyarakat antarwilayah, yang dapat mengganggu stabilitas keamanan negara akibat kecemburuan masyarakat terutama yang berasal dari daerah dengan tingkat kesejahteraan lebih rendah.

Meskipun kesenjangan antarwilayah hampir tidak mungkin dihilangkan sama sekali, namun upaya untuk mengurangi tingkat kesenjangan antarwilayah perlu dilakukan. Hal ini untuk menghindari berbagai dampak negatif yang dapat ditimbulkan akibat tingginya kesenjangan antarwilayah. Tingginya kesenjangan antarwilayah dapat mengancam kestabilan kondisi sosial-ekonomi diantaranya:

a. Tingginya kesenjangan antarwilayah memiliki potensi dampak negatif terutama terhadap kohesi sosial politik. Meskipun pertumbuhan ekonomi berlangsung cukup tinggi, namun akan muncul persepsi publik bahwa kesejahteraan belum dapat dinikmati oleh semua orang, sehingga keadilan dan pemerataan belum terjadi;

b. Kesenjangan yang meningkat akan mengurangi pertumbuhan ekonomi melalui beberapa hal, diantaranya: perubahan pola permintaan, perubahan ukuran pasar domestik, berkurangnya kegiatan kewirausahaan, keterkaitan ekonomi politik dan instabilitas bagi perlambatan pertumbuhan ekonomi, dan lain sebagainya;

c. Ketidakmampuan kelompok miskin kronis keluar dari kemiskinan akan memperlebar kesenjangan dan melemahkan pertumbuhan ekonomi. Dalam hal ini masih cukup besar jumlah masyarakat miskin dan rentan yang tidak terlindungi atau mendapatkan manfaat bantuan dan jaminan sosial.

\subsection{Otonomi Daerah dan Desentralisasi}

Sejak diterapkannya UU No. 29 tahun 1999 yang direvisi menjadi UU No. 32 tahun 2004 dan direvisi lagi menjadi UU No. 34 Tahun 2014, telah terjadi pergeseran pelaksanaan administrasi publik di Indonesia yang semula menganut asas sentralisasi menjadi desentralisasi. Dengan penerapan sistem desentralisasi ini maka pemerintah daerah mempunyai wewenang untuk mengatur dan mengurus urusan pemerintahan dan kepentingan masyarakat setempat menurut prakarsa sendiri berdasarkan aspirasi masyarakat sesuai dengan peraturan perundangundangan. Berdasarkan UU No. 34 Tahun 2014, yang dimaksud dengan desentralisasi adalah penyerahan urusan pemerintahan oleh pemerintah pusat kepada daerah otonom berdasarkan asas otonomi.

Sebagaimana diamanatkan oleh Undang-Undang Dasar Negara Republik Indonesia Tahun 1945, terdapat urusan pemerintahan yang sepenuhnya menjadi kewenangan pemerintah pusat yang dikenal dengan istilah urusan pemerintahan absolut dan ada urusan pemerintahan konkuren. Urusan pemerintahan konkuren terdiri atas urusan pemerintahan wajib dan urusan pemerintahan pilihan yang dibagi antara pemerintah pusat, daerah provinsi, dan daerah kabupaten/kota. Berdasarkan urusan konkuren tersebut dilakukan pembagian kewenangan antara pemerintah, pemerintah provinsi, dan pemerintah kabupaten/kota. urusan pemerintah konkuren yang diserahkan ke daerah menjadi dasar pelaksanaan otonomi daerah.

Otonomi Daerah adalah hak, wewenang, dan kewajiban daerah otonom untuk mengatur dan mengurus sendiri urusan pemerintahan dan kepentingan 
masyarakat setempat dalam sistem Negara Kesatuan Republik Indonesia (UU No. 23/2014). Pemberian otonomi yang seluas-luasnya kepada daerah diarahkan untuk mempercepat terwujudnya kesejahteraan masyarakat melalui peningkatan pelayanan, pemberdayaan, dan peran serta masyarakat. Di samping itu melalui otonomi luas dalam lingkungan strategis globalisasi, diharapkan daerah mampu meningkatkan daya saing dengan memperhatikan prinsip demokrasi, pemerataan, keadilan, keistimewaan dan kekhususan serta potensi dan keanekaragaman daerah dalam sistem Negara Kesatuan Republik Indonesia. Dalam menjalankan otonomi daerah, kebijakan yang dibuat dan dilaksanakan oleh daerah merupakan bagian integral dari kebijakan nasional. Perbedaannya adalah terletak pada bagaimana memanfaatkan kearifan, potensi, inovasi, daya saing, dan kreativitas daerah untuk mencapai tujuan nasional tersebut di tingkat lokal yang pada gilirannya akan mendukung pencapaian tujuan nasional secara keseluruhan.

Pelaksanaan otonomi daerah pada dasarnya bertujuan agar daerah terdorong untuk kreatif dalam mengelola sumber daya yang dimilikinya dalam melakukan pembangunan sesuai dengan kebutuhan dan karakteristik masingmasing daerah. Pada umumnya desentralisasi dilaksanakan oleh adanya dorongan politik yang bertujuan untuk: (1) meningkatkan wewenang dan tanggung jawab pemerintah daerah; (2) meningkatkan keikutsertaan masyarakat dan penyelenggaraan pelayanan masyarakat, yang responsif terhadap kebutuhan masyarakat; (3) memperkuat kerja sama dan integrasi pelayanan masyarakat di daerah; (4) restrukturisasi dan efisiensi pelayanan masyarakat; serta (5) mendukung inovasi dan pengembangan pelayanan masyarakat.

Pelaksanaan otonomi daerah dan desentralisasi pembangunan diyakini juga dapat digunakan untuk mengurangi tingkat kesenjangan pembangunan antarwilayah. Hal ini jelas karena dengan dilaksanakannya otonomi daerah dan desentralisasi pembangunan daerah, termasuk daerah terbelakang akan dapat lebih digerakkan karena ada wewenang yang berada pada pemerintah daerah dan masyarakat tersebut. Dengan adanya kewenangan tersebut, maka berbagai inisiatif dan aspirasi masyarakat untuk menggali potensi daerah akan lebih dapat digerakkan. Bila hal ini dapat dilakukan, maka proses pembangunan daerah secara keseluruhan akan dapat lebih ditingkatkan dan secara bersamaan ketimpangan pembangunan antar wilayah dapat pula dikurangi.

Berdasarkan hal tersebut, upaya pengurangan kesenjangan wilayah dan pengentasan kemiskinan serta pemerataan pembangunan yang mengacu pada berbagai hal yang termasuk dalam urusan konkuren perlu dilakukan pula oleh Pemerintah Daerah sesuai dengan pembagian kewenangan yang diatur dalam UU Nomor 23 Tahun 2014. Pengembangan upaya pengurangan kesenjangan dan pengentasan kemiskinan serta pemerataan pembangunan yang dilakukan di daerah ditujukan untuk mengejar ketertinggalan daerah terhadap wilayah lainnya dalam rangka pengurangan kesenjangan wilayah secara nasional, penurunan tingkat kemiskinan untuk mengejar ketertinggalan wilayah, maupun mengurangi kesenjangan antarwilayah di wilayahnya masing-masing. Pengembangan upaya tersebut tentunya memanfaatkan kearifan masing-masing wilayah, potensi yang dimiliki, daya saing wilayah, kreativitas daerah, maupun inovasi daerah.

Inovasi yang dilakukan pada suatu daerah dapat mendorong majunya daerah tersebut dibanding daerah lainnya. Oleh karenanya, diperlukan upaya dan perlindungan untuk mendorong setiap kegiatan yang bersifat inovatif di daerah dalam rangka memajukan daerahnya dan menyejahterakan masyarakatnya. 


\subsection{Inovasi}

Inovasi adalah sebuah ide, praktik atau objek yang dianggap baru oleh individu. Inovasi dapat berupa produk atau jasa baru, teknologi proses produksi yang baru, sistem struktur dan administrasi baru atau rencana baru bagi anggota organisasi. Pada dasarnya terdapat berbagai definisi terkait dengan inovasi. Undang-undang Nomor 18 Tahun 2002 mendefinisikan Inovasi sebagai kegiatan penelitian, pengembangan, dan/atau perekayasaan yang bertujuan mengembangkan penerapan praktis nilai dan konteks ilmu pengetahuan yang baru, atau cara baru untuk menerapkan ilmu pengetahuan dan teknologi yang telah ada ke dalam produk atau proses produksi. Definisi yang dikemukakan oleh peraturan perundangundangan tersebut lebih mengacu pada inovasi terhadap penerapan ilmu pengetahuan dan teknologi.

Dalam literatur modern, inovasi sendiri memiliki pengertian yang sangat beragam serta banyak perspektif yang mencoba memaknainya. Salah satu pengertian menyebutkan bahwa inovasi adalah kegiatan yang meliputi seluruh proses menciptakan dan menawarkan jasa atau barang baik yang sifatnya baru, lebih baik atau lebih murah dibandingkan dengan yang tersedia sebelumnya. Pengertian ini menekankan pemahaman inovasi sebagai sebuah kegiatan (proses) penemuan (invention). Sedangkan dalam Damanpour dijelaskan bahwa sebuah inovasi dapat berupa produk atau jasa yang baru, teknologi proses produksi yang baru, sistem struktur dan administrasi baru atau rencana baru bagi anggota organisasi.

Sejalan dengan itu menurut Everett M. Rogers (1983), salah satu penulis buku inovasi terkemuka, menjelaskan bahwa an innovation is an idea, practice, or object that is perceived as new by individual or other unit of adopter. Jadi inovasi adalah suatu ide, gagasan, praktik atau objek/benda yang disadari dan diterima sebagai suatu hal yang baru oleh seseorang atau kelompok untuk diadopsi.

Pengertian dari Damanpour maupun Rogers ini menunjukkan bahwa inovasi dapat merupakan sesuatu yang berwujud (tangible) maupun sesuatu yang tidak berwujud (intangible). Sehingga dimensi dari inovasi sangatlah luas. Memaknai inovasi sebagai sesuai yang hanya identik dengan teknologi saja akan jadi menyempitkan konteks inovasi yang sebenarnya. Sedang Stephen Robbins (1994) mengemukakan bahwa Inovasi adalah suatu gagasan baru yang diterapkan untuk memprakarsai atau memperbaiki suatu produk atau proses dan jasa.

\section{Permasalahan}

Berdasarkan uraian di atas, pada dasarnya Indonesia masih menghadapi permasalahan dan tantangan terkait kesenjangan antar-wilayah, baik antara kawasan Barat dan kawasan Timur Indonesia, antara kawasan perkotaan dan perdesaan, antara kawasan perbatasan dan hinterland, dan lain sebagainya.

Kesenjangan antarwilayah di Indonesia tidak terlepas dari adanya keragaman potensi sumber daya alam, letak geografis, kualitas sumber daya manusia, ikatan etnis atau politik. Keberagaman ini dapat menjadi sebuah keunggulan dalam satu sisi, namun disisi lain dapat berpotensi menjadi sumber instabilitas sosial dan politik nasional. Dalam konteks kenegaraan kesenjangan akan mengurangi kepercayaan masyarakat terhadap pemerintah yang kemudian akan mengancam keutuhan suatu negara. Kesenjangan antarwilayah juga dapat mengakibatkan instabilitas. Kesenjangan antarwilayah yang terjadi di Indonesia selain mengakibatkan adanya perbedaan tingkat kesejahteraan ekonomi masyarakat, 
juga dapat mendorong timbulnya kecemburuan sosial dari masyarakat di wilayah yang kurang berkembang terhadap masyarakat yang lebih maju.

Oleh karenanya perhatian terhadap upaya pengurangan kesenjangan wilayah perlu menjadi prioritas pembangunan. Meskipun tidak bisa dihilangkan sepenuhnya, kesenjangan antarwilayah tetap harus diupayakan untuk dikurangi. Salah satu prinsip dasar yang harus dipegang para pengambil kebijakan adalah bahwa kesenjangan perekonomian antarwilayah masih dapat ditoleransi sejauh tidak mengganggu pertumbuhan ekonomi nasional dan tidak menciptakan ketidakmerataan pendapatan yang luar biasa dalam masyarakat. Dengan kata lain, upaya melakukan redistribusi pendapatan masyarakat haruslah mendapatkan prioritas utama dibandingkan redistribusi perekonomian daerah.

Sejalan dengan upaya yang dilakukan oleh pemerintah, seiring dengan berkembangnya otonomi daerah dan desentralisasi, upaya pengurangan kesenjangan antarwilayah juga perlu dilakukan di tingkat pemerintah daerah, baik dalam rangka mengejar ketertinggalan wilayahnya maupun dalam rangka mengurangi kesenjangan antarwilayah di masing-masing wilayahnya. Upaya pengurangan kesenjangan antarwilayah yang dilakukan di daerah tentu saja perlu disesuaikan dengan karakteristik dan kondisi serta permasalahan yang dihadapi masing-masing daerah. Otonomi daerah memberi keleluasaan untuk upaya kreativitas dan inovasi bagi daerah dalam mengembangkan kebijakan dan strategi untuk mengurangi kesenjangan antarwilayah di masing-masing daerah.

Upaya prakarsa inovasi di daerah dalam rangka mengurangi kesenjangan antarwilayah tersebut perlu didorong dan dikembangkan. Untuk itu diperlukan pemahaman terhadap upaya dan prakarsa dari berbagai inovasi yang telah dilakukan di daerah dalam rangka mengurangi kesenjangan antarwilayah.

Hal inilah yang mendasari dilakukannya penelitian terhadap prakarsa dan inovasi di daerah dalam rangka mengurangi kesenjangan antarwilayah. Penelitian ini dilakukan untuk menghasilkan masukan bagi penyiapan rekomendasi untuk penyiapan kebijakan bagi upaya untuk lebih mendorong prakarsa daerah dalam pengurangan kesenjangan antarwilayah maupun memberikan rekomendasi bagi upaya replikasi praktik-praktik baik (good practices) yang sudah dilakukan.

\section{Analisis}

\subsection{Praktik Inovasi di Daerah}

Dengan semakin berkembangnya pelaksanaan otonomi daerah, kegiatan inovasi di daerah semakin berkembang. Inovasi yang dilakukan pemerintah daerah pada dasarnya dapat meliputi berbagai sektor dengan tujuan yang beragam. Namun secara umum inovasi yang dilakukan di daerah dilaksanakan dalam rangka meningkatkan pelayanan publik dan kesejahteraan masyarakat.

Inovasi yang dilakukan oleh Pemerintah Daerah pada dasarnya tidak selalu bertujuan utama untuk mengurangi kesenjangan antarwilayah. Namun demikian, sejumlah program inovasi dipandang mendorong upaya untuk pengurangan kesenjangan antarwilayah, baik untuk mengurangi kesenjangan wilayahnya terhadap wilayah lainnya maupun dalam rangka mengurangi kesenjangan di dalam wilayahnya sendiri.

Secara umum inovasi/prakarsa daerah terkait pengurangan kesenjangan antarwilayah dapat dikategorikan sebagai berikut : 
a. Inovasi Adoptif, yaitu inovasi yang bersumber pada program-program yang sebelumnya telah ada, dan dinilai cukup berhasil oleh pemerintah daerah. Untuk selanjutnya ditiru seutuhnya atau diambil sebagian dari program tersebut dengan nama program yang sama atau nama baru. Yang membedakan hanya sumber dan alokasi pembiayaan, serta penanggung jawab kegiatan. Program-program yang bersifat inovasi adoptif memiliki kelebihan dan kekurangan/kelemahan, antara lain: mudah untuk diikuti oleh masyarakat (tidak perlu sosialisasi), karena yang menjadi kelompok sasaran biasanya telah mengenal dengan baik program-program yang ditawarkan karena telah ada sebelumnya. Bagi program-program sebelumnya yang dianggap berhasil akan diikuti oleh masyarakat secara pastisipatif. Namun, sebaliknya bila belum menunjukkan keberhasilan akan sukar mengajak masyarakat untuk mau berpartisipasi di dalamnya. Terlebih bila kinerja pemerintah setempat dinilai rendah oleh masyarakat. Sehingga akan menjadi hal yang sia-sia saja. Bahkan ada kesan pemerintah melaksanakan program hanya untuk menghabiskan anggaran, bukan untuk kesejahteraan rakyat. Adopsi inovasi dapat dilakukan baik bersumber dari program sejenis yang sudah dilakukan di daerah lain, program yang dilakukan oleh pemerintah (pusat), maupun program yang sudah dilakukan oleh lembaga lain. Contoh inovasi adoptif diantaranya adalah program pemberian stimulan berupa modal bergulir seperti yang dilakukan pada Program Desa Mandiri Anggur Merah (provinsi NTT), Program Jalin Matra (provinsi Jawa Timur), Program Pemberdayaan Ekonomi Masyarakat (kota Kupang), Program Kredit Melati (kota Bandung), Program Brigade Kupang Sehat (kota Kupang), dan lain sebagainya. Meskipun sifatnya mengadaptasi program lain, namun masing-masing program memiliki karakteristik yang berbeda satu dengan lainnya disesuaikan dengan kondisi masing-masing daerah, seperti kemampuan keuangan, kearifan, kapasitas SDM, kreativitas daerah, dan lain sebagainya.

b. Inovasi Instruktif, yaitu inovasi yang dilakukan pemerintah daerah yang bersumber pada Instruksi Presiden (Inpres), Keputusan Presiden (Keppres), Keputusan Menteri (KepMen), dan sebagainya, yang pada prinsipnya berasal dari kebijakan pemerintah pusat. Program-program tersebut biasanya dilaksanakan berdasarkan pada Juknis atau Juklak baku yang dibuat pemerintah pusat untuk dilaksanakan di daerah-daerah. Klaim-klaim atas keberhasilan yang diraih dari program yang bersifat instruktif tidak salah untuk disampaikan kepada publik. Hanya saja kembali pada prinsip-prinsip yang terkandung pada Undang-Undang Otonomi Daerah yaitu, demokrasi, pemerataan, keadilan, keistimewaan dan kekhususan suatu daerah dalam sistem Negara Kesatuan Republik Indonesia, maka jelas bahwa adanya pengakuan atas kekhasan dari setiap daerah diperlukan pola kerja yang berbeda pula. Karena, salah satu sumber kegagalan sebuah program pemerintah adalah program-program yang ditawarkan bersifat umum (yang kebanyakan mengadopsi di pulau Jawa). Beberapa program inovasi yang dilakukan oleh pemerintah daerah dilakukan dengan mengacu pada instruksi yang diamanatkan oleh pemerintah pusat. Program dipandang sebagai inovasi karena daerah tersebut merupakan daerah pertama yang menerapkan program pemerintah dibanding daerah di sekitarnya. Contoh inovasi instruktif diantaranya adalah Program Desa Siaga, Program Tanimas, dan lain sebagainya. 
c. Inovasi Mandiri, yaitu terobosan-terobosan inovatif pemerintah daerah yang dilakukan atas dasar kebutuhan, yaitu kebutuhan untuk menyelesaikan masalah yang ada di masyarakat. Inovasi yang dihasilkan disesuaikan dengan kondisi lingkungan yang ada dan kemampuan yang dimiliki. Meskipun belum banyak program inovasi yang benar-benar inovasi mandiri berupa terobosan inovatif pemerintah daerah, namun program inovasi tersebut sudah mulai muncul. Contoh inovasi mandiri diantaranya adalah Gerakan Bela Beli Kulonprogo, pengembangan kawasan pariwisata Diamond Triangle, dan lain sebagainya.

\subsection{Tahapan Inovasi}

Pemilihan bentuk dan jenis inovasi perlu didasarkan pada pemahaman terhadap permasalahan yang dihadapi, baik di bidang ekonomi, pendidikan, kesehatan, dan infrastruktur. Pemahaman permasalahan dapat diidentifikasi berdasarkan tahapan perkembangan masing-masing bidang. Penetapan program inovasi didasarkan pada permasalahan yang dihadapi. Pemahaman terhadap tahapan/kedudukan permasalahan akan mendorong ketepatan pencapaian efektivitas tujuan inovasi.

Penetapan program inovasi untuk pengurangan kesenjangan wilayah yang sudah dilakukan pada dasarnya dapat dikelompokkan berdasarkan tahapan (klasifikasi) permasalahan yang dihadapi. Permasalahan di bagian hulu diatasi dengan inovasi pada penyelesaian persoalan penyediaan kebutuhan dasar. Selanjutnya permasalahan di bagian hilir diatas dengan inovasi untuk peningkatan kualitas pada sektor yang dituju.

\subsubsection{Tahapan Inovasi Bidang Ekonomi}

Bentuk dan jenis inovasi di bidang ekonomi perlu disiapkan dengan memperhatikan tahapan dan tingkat permasalahan ekonomi yang dihadapi. Secara umum upaya peningkatan pendapatan masyarakat perlu dilakukan terhadap 2 (dua) kelompok, kelompok pertama adalah masyarakat yang memperoleh pendapatan dari upah/gaji sedang kelompok kedua adalah masyarakat yang memperoleh pendapatan dari surplus usaha. Dari sisi masyarakat yang memperoleh pendapatan dari upah/gaji permasalahan masyarakat miskin adalah rendahnya gaji/upah yang diterima disebabkan keterampilan yang terbatas dan sikap mental yang buruk. Rendahnya keterampilan masyarakat disebabkan akses atau kesempatan untuk mendapatkan pelayanan pendidikan dan kesehatan pada umumnya kurang memadai. Pada kelompok masyarakat ini maka upaya peningkatan pendapatan masyarakat perlu diupayakan pada tindakan afirmatif (sebagai contoh pemberian subsidi pendidikan, pemberian bantuan pemenuhan kebutuhan dasar, pemberian bantuan akses pelayanan kesehatan, dan lain sebagainya) yang diberikan dalam program inovasi bidang lainnya.

Sedang dari sisi masyarakat yang memperoleh pendapatan dari surplus produksi, upaya peningkatan pendapatan dapat dilakukan dengan meningkatkan usahanya untuk dapat memperoleh surplus produksi yang lebih besar. Sebagian besar masyarakat berpenghasilan rendah yang mengandalkan pendapatannya dari surplus produksi menghadapi kendala terkait modal (termasuk lahan), kemampuan sumberdaya manusia (penguasaan teknologi), dan distribusi (baik pada pasar input maupun pada 
pasar output atau pasar barang). Keempat kendala tersebut saling berkaitan satu sama lainnya. Oleh sebab itu perlu pemahaman yang baik terhadap letak permasalahan yang paling signifikan yang dihadapi.

Secara umum ditinjau dari sistem produksi, tahapan permasalahan pada kelompok masyarakat yang memperoleh pendapatan dari surplus produksi dapat dikelompokkan sebagai berikut:

1. Tahap peningkatan produktivitas

Pada tahapan ini permasalahan utama yang dihadapi adalah upaya untuk peningkatan produktivitas. Umumnya hal ini dialami oleh petani, peternak, nelayan, dan lain sebagainya yang belum mampu memenuhi tingkat produktivitas yang tinggi. Hal ini umumnya ditandai dengan keterbatasan penguasaan modal (termasuk lahan), keterbatasan penguasaan teknologi (sumber daya manusia), keterbatasan prasarana dan sarana pendukung untuk produksi, dan lain sebagainya. Oleh karenanya inovasi untuk peningkatan pendapatan kelompok ini ditujukan untuk meningkatkan produktivitas melalui fasilitas modal, fasilitasi penyediaan prasarana dan sarana pendukung, peningkatan kapasitas SDM dan penguasaan teknologi, dan lain sebagainya. Program inovasi yang umum dilakukan diantaranya adalah bantuan stimulan berupa penyediaan prasarana dan sarana untuk mendukung peningkatan produksi, penyediaan teknologi untuk meningkatkan produksi, peningkatan kapasitas SDM, bantuan modal, peningkatan ekstensifikasi dan intensifikasi, dan lain sebagainya. Ditinjau dari pendekatan inovasi yang digunakan dapat berupa pemberian stimulan berupa modal kerja dan penyediaan prasarana dan sarana maupun teknologi, pendampingan teknis untuk penguasaan teknologi dan peningkatan kapasitas SDM, dan advokasi. Inovasi untuk peningkatan produktivitas bahan baku umumnya dikembangkan di wilayah yang masih menghadapi persoalan rendahnya produktivitas bahan baku, terutama di luar Pulau Jawa.

2. Tahap peningkatan nilai tambah

Karakteristik permasalahan yang dihadapi pada tahapan ini umumnya adalah surplus produksi dan belum adanya peningkatan nilai tambah dari produk bahan baku yang dihasilkan. Umumnya pada tahapan ini produktivitas sudah tidak menjadi permasalahan yang signifikan, namun pendapatan masyarakat relatif masih rendah karena belum efektifnya pembentukan nilai tambah dari produk yang dihasilkan. Upaya untuk peningkatan pendapatan masyarakat dalam kelompok ini ditujukan untuk peningkatan nilai tambah bagi surplus produksi yang dihasilkan serta peningkatan kualitas bahan jadi atau bahan setengah jadi yang dihasilkan. Bentuk inovasi yang umum diberikan umumnya berupa pendampingan teknis untuk meningkatkan nilai tambah produk bahan baku, pendampingan teknis untuk peningkatan kualitas produk bahan baku maupun bahan setengah jadi/bahan jadi, pengembangan jejaring pasar, pemberian bantuan modal, peningkatan kapasitas SDM, pemberian bantuan prasarana dan sarana untuk meningkatkan nilai tambah, dan lain sebagainya. Oleh karenanya inovasi yang dikembangkan diantaranya dilakukan dengan 
pendekatan pendampingan teknis untuk peningkatan nilai tambah maupun peningkatan kualitas produksi bahan setengah jadi atau bahan jadi yang dihasilkan, fasilitas pasar untuk produk nilai tambah yang dihasilkan, advokasi, dan stimulan berupa pemberian modal usaha.

3. Tahap perluasan pasar

Karakteristik permasalahan yang dihadapi pada tahap ini adalah terkait pengembangan pasar. Pada umumnya pada tahapan ini produktivitas sudah bukan menjadi masalah, bahkan upaya untuk peningkatan produktivitas relatif tidak diperlukan karena sudah mencapai efektivitas produksi yang cukup baik. Upaya untuk peningkatan nilai tambah juga sudah banyak dikembangkan dan sudah mampu memproduksi dalam jumlah yang cukup besar. Persoalan terutama terkait pemasaran produk-produk yang dihasilkan. Inovasi pada tahapan ini ditujukan bagi perluasan pasar untuk meningkatkan penjualan produk-produk yang dihasilkan. Peningkatan pasar dapat dilakukan dengan memperluas pasar maupun menciptakan pasar baru melalui diversifikasi produk dan penciptaan demand baru. Inovasi yang dilakukan umumnya dalam bentuk pendampingan teknis untuk pemasaran produk, pendampingan teknis untuk peningkatan kualitas produk, fasilitasi peningkatan jejaring pasar, bantuan modal, dan lain sebagainya. Pendekatan yang digunakan diantaranya adalah bantuan stimulan untuk peningkatan permodalan, penyediaan pendampingan teknis, fasilitas pasar, dan lain sebagainya.

Pemahaman yang baik terhadap tahapan permasalahan yang dihadapi dalam sistem tahapan pengembangan ekonomi akan mendorong efektivitas inovasi yang dilakukan. Sebagai contoh invasi Gerakan Bela Beli Kulonprogo yang digagas Pemerintah Kabupaten Kulonprogo dalam mengembangkan pasar lokal bagi produk-produk setempat merupakan hasil dari pemahaman yang baik terhadap permasalahan yang dihadapi di wilayahnya. Pemerintah Kabupaten Kulonprogo memahami bahwa permasalahan peningkatan produktivitas pertanian tanaman pangan bukan lagi menjadi permasalahan yang dihadapi petani. Namun untuk meningkatkan pendapatan masyarakat, petani masih menghadapi kendala terkait efisiensi biaya produksi dan pemasaran produk (termasuk memperkecil rantai pasok). Oleh karenanya Pemerintah Kabupaten Kulonprogo mengembangkan pasar beras masyarakat setempat melalui kerjasama dengan Bulog Divre Yogyakarta untuk memasok beras Raskin bagi masyarakat Kulonprogo serta pemasaran beras premium kepada PNS yang dipasok langsung oleh Gapoktan (Gabungan Kelompok Petani).

Umumnya permasalahan ekonomi di wilayah Pulau Jawa tidak lagi terkait pada permasalahan produktivitas, namun lebih pada upaya untuk peningkatan nilai tambah, peningkatan efisiensi biaya produksi, maupun pemasaran produk. Sedang permasalahan ekonomi di luar Pulau Jawa sebagian masih pada tahapan peningkatan produktivitas. Dengan demikian inovasi bidang ekonomi yang dilakukan di Pulau Jawa maupun di luar Pulau Jawa relatif berbeda karakteristik dan pendekatannya. 


\subsubsection{Tahapan Inovasi Bidang Pendidikan}

Tingkat permasalahan di bidang pendidikan secara umum dapat dikategorikan dalam 3 (tiga) kelompok, yaitu:

1. Permasalahan pada peningkatan akses pelayanan pendidikan

Daerah yang menghadapi permasalahan ini umumnya dihadapkan pada berbagai kendala masyarakat untuk dapat mengakses pelayanan pendidikan, seperti terbatasnya kemampuan masyarakat untuk menyekolahkan anaknya, keterbatasan aksesibilitas menuju sekolah, keterbatasan prasarana dan sarana pendidikan, dan lain sebagainya. Untuk mengatasi permasalahan tersebut, inovasi yang dilakukan ditujukan untuk meningkatkan akses masyarakat terhadap pelayanan pendidikan. Bentuk inovasi yang diberikan diantaranya berupa pemberian bantuan biaya pendidikan, pemberian bantuan fasilitas transportasi untuk bersekolah, pemberian bantuan penyediaan prasarana dan sarana sekolah, dan lain sebagainya. Sedang pendekatan yang dapat digunakan diantaranya adalah peningkatan akses layanan pendidikan, pemberian bantuan prasarana dan sarana, serta advokasi. Contoh inovasi yang dilakukan diantaranya adalah Pelayanan Bus Sekolah Gratis (Kabupaten Pakpak Barat), Program Basakolah, Program Sumikolah, dan lain sebagainya.

2. Permasalahan Peningkatan Kualitas Pendidikan

Daerah yang mengembangkan inovasi ini umumnya sudah tidak lagi menghadapi permasalahan keterbatasan akses masyarakat terhadap layanan pendidikan. Oleh karenanya upaya yang dilakukan diarahkan untuk peningkatan kualitas pendidikan serta pemerataannya ke seluruh wilayah. Program inovasi yang dilakukan dapat berupa peningkatan prasarana dan sarana pendidikan untuk peningkatan kualitas pendidikan, peningkatan kapasitas guru dan pendidik, pengembangan metode pengajaran, advokasi, dan lain sebagainya.

3. Permasalahan Pengembangan Sistem Pendidikan

Pada tahap yang tertinggi adalah inovasi terkait untuk pengembangan sistem pendidikan. Pada tahapan ini kualitas pendidikan umumnya sudah relatif baik, demikian pula dengan ketersediaan prasarana dan sarana pendidikan. Namun demikian untuk lebih meningkatkan daya saing pendidikan, dibutuhkan peningkatan/pembaruan sistem pendidikan. Tujuannya adalah perubahan sistem dan tata kelola pendidikan untuk meningkatkan daya saing pendidikan di wilayahnya.

Oleh karena inovasi di bidang pendidikan yang dipandang terkait upaya pengurangan kesenjangan antarwilayah difokuskan pada inovasi untuk meningkatkan IPM bidang pendidikan, terutama pada penurunan tingkat putus sekolah serta peningkatan lama pendidikan siswa, maka inovasi yang dilakukan adalah pada upaya tahapan pertama, yaitu peningkatan akses pendidikan. Bentuk dan pendekatan yang digunakan dapat berupa pemberian bantuan akses ke layanan pendidikan, peningkatan prasarana dan sarana pendidikan, maupun advokasi untuk meningkatkan kesadaran masyarakat terhadap pentingnya pendidikan. 
Permasalahan akses terhadap fasilitas pendidikan masih banyak dirasakan oleh masyarakat di luar Pulau Jawa. Oleh karenanya, inovasi bidang pendidikan terutama untuk menurunkan angka putus sekolah serta meningkatkan lama pendidikan siswa lebih banyak dilakukan di luar Pulau Jawa. Inovasi tersebut sebagian besar dilakukan dengan pemberian akses terhadap pelayanan pendidikan bagi masyarakat.

\subsubsection{Tahapan Inovasi Bidang Kesehatan}

Permasalahan di bidang kesehatan juga dapat dikelompokkan berdasarkan tahapan permasalahan yang dihadapi, yaitu:

1. Tahap Kuratif

Permasalahan pada tahapan ini umumnya ditandai dengan masih rendahnya kualitas kesehatan masyarakat serta akses masyarakat terhadap layanan kesehatan. Upaya penurunan angka kematian ditujukan terutama pada upaya penyembuhan penyakit, percepatan penanganan masalah kesehatan masyarakat, serta peningkatan akses masyarakat pada layanan kesehatan. Bentuk inovasi yang umum dilakukan diantaranya adalah pemberian akses layanan kesehatan melalui Jamkesda maupun asuransi kesehatan lainnya, peningkatan prasarana dan sarana kesehatan, serta advokasi untuk meningkatkan kesadaran masyarakat. Contoh inovasi yang dilakukan diantaranya adalah bantuan Jamkesda atau asuransi kesehatan lainnya yang dilakukan oleh berbagai daerah, layanan rawat inap tanpa kelas bagi keluarga miskin (Kabupaten Kulonprogo), program Dokter Online, dan lain sebagainya.

2. Tahap Preventif

Permasalahan utama pada tahapan ini tidak lagi difokuskan pada peningkatan akses masyarakat pada layanan kesehatan, tetapi pada upaya untuk meningkatkan pencegahan penyakit serta peningkatan kesadaran masyarakat pada upaya preventif. Pada tahapan ini peningkatan kualitas kesehatan masyarakat sudah mulai menjadi perhatian. Pendekatan inovasi yang dilakukan diantaranya berupa penyediaan prasarana dan sarana kesehatan serta advokasi untuk meningkatkan kesadaran masyarakat terhadap upaya preventif. Beberapa contoh inovasi pada tahap ini diantaranya adalah Program Kesehatan Reproduksi (Kespro), program pemberdayaan kelompok pendukung ASI (KP-ASI), program Brigade Kupang Sehat, dan lain sebagainya.

3. Tahap Peningkatan Kualitas Layanan Kesehatan

Pada tahapan ini upaya peningkatan kesehatan masyarakat difokuskan pada upaya untuk peningkatan kualitas layanan kesehatan. Umumnya akses masyarakat terhadap layanan kesehatan sudah cukup baik, tinggal meningkatkan kualitas layanan kesehatan yang disediakan. Bentuk inovasi yang dilakukan dapat menggunakan pendekatan penyediaan prasarana dan sarana yang berkualitas, advokasi, serta peningkatan kemampuan penyembuhan penyakit. 


\subsection{Rentang Kendali}

Definisi rentang kendali (span of control) menurut business dictionary ${ }^{s}$ adalah jumlah subordinat yang menunjukkan seorang manajer/pengelola dapat langsung melakukan kontrol. Tujuan adanya kendali adalah pengawasan dan pengendalian terhadap bawahannya agar berjalan secara efektif. Prinsip pengelolaan yang ditawarkan Gulick dan Urwick (1937) menunjukkan bahwa jenjang hierarkis yang tidak terlalu panjang, aktivitasnya akan lebih mudah dikendalikan.

Dalam pengelolaan pengurangan kesenjangan wilayah, terdapat beberapa rentang kendali. Organisasi pemerintahan di Indonesia baik di masing-masing pemerintah pusat maupun daerah memiliki rentang kendali yang panjang, hal ini tercermin dari jumlah hierarki yang panjang. Sedangkan organisasi masyarakat atau lembaga non pemerintah umumnya memiliki rentang kendali yang lebih pendek. Dalam pelaksanaannya, ternyata rentang kendali tersebut menentukan keefektifan dalam keberhasilan pengurangan kesenjangan. Berikut adalah jenis rentang kendali yang selama ini berjalan di Indonesia untuk melaksanakan pengurangan kesenjangan wilayah, yaitu:

a. Rentang kendali pemerintah pusat-pemerintah daerah

Dengan prinsip desentralisasi, pemerintah pusat memiliki program yang dijalankan oleh pemerintah daerah, bahkan sampai dengan tingkat pemerintahan desa. Contoh: Program Dana Desa dari KPDT;

b. Rentang kendali pemerintah daerah

Terdapat dua jenis rentang kendali di pemerintahan daerah. Yaitu rentang kendali program yang dijalankan oleh pemerintah provinsi ke masing-masing kabupaten/kota, bahkan sampai dengan masyarakat penerima program, yang menunjukkan rentang kendali yang cukup panjang; dan rentang kendali di pemerintah kabupaten/kota sendiri yang relatif cukup pendek;

c. Rentang kendali organisasi masyarakat dan lembaga non pemerintah

Rentang kendali pada organisasi ini relatif pendek karena struktur organisasi yang sederhana dan tidak banyak berhierarki. Organisasi masyarakat yang biasanya terlibat contohnya adalah asosiasi pengusaha, asosiasi petani, koperasi, atau LSM yang terlibat dalam pengurangan kesenjangan wilayah.

Bila melihat tahapan pelaksanaan kegiatan/program yang meliputi perencanaan, implementasi, dan evaluasi, maka secara umum tahapan perencanaan dapat dilakukan dengan baik dan menghasilkan perencanaan (walaupun tetap memiliki keterbatasan). Namun, seiring dengan semakin panjang rentang kendali dari perencana program dengan penerima manfaat, maka tingkat efektivitas pengurangan kesenjangan wilayah relatif makin berkurang, terutama dalam pengawasan dan pengendalian program (penilaian keberhasilan, keterserapan, dan keberlanjutan program). Program inovasi pengurangan kesenjangan antar wilayah yang digagas oleh pemerintah dengan hierarki yang lebih tinggi memiliki rentang kendali yang lebih panjang dibanding dengan inovasi yang digagas oleh pemerintah dengan hierarki yang lebih rendah. Masalah muncul pada saat implementasi terutama saat kegiatan verifikasi, pendampingan, dan fasilitasi program harus

s (http://www.businessdictionary.com/definision/span-of-control.html) 
melibatkan kegiatan pemberdayaan dan analisis target masyarakat sasaran dengan jelas.

Dengan rentang kendali yang semakin panjang, upaya verifikasi, fasilitasi, dan pendampingan tersebut tidak lagi bersifat seragam untuk semua wilayah. Kebutuhan atas fasilitator atau pendamping yang baik menjadi sulit diterapkan karena proses kaderisasi atau pelatihan pun tidak berjalan baik. Bila rentang kendali organisasi dengan tingkat struktur organisasi yang pendek lebih mudah untuk menilai tingkat keberhasilannya, dan menjamin keberlangsungan programnya. Selain keefektifan rentang kendali berdasarkan tahapan pelaksanaan kegiatan/program, maka efektivitas dapat dilihat juga terhadap pemahaman wilayah dari target wilayah yang disasar.

Makin tinggi rentang kendali, maka program yang disusun makin seragam tanpa melihat karakteristik wilayah, walaupun perencanaan cukup komprehensif dan anggaran besar. Namun kegagalan pengurangan kesenjangan muncul karena program yang diberikan tidak cocok dengan kondisi wilayah dan kondisi sosial budaya masyarakat. Pengenalan dan pemahaman karakter daerah menjadi sulit dilakukan pada saat rentang kendali makin tinggi.

\subsection{Kelembagaan}

Secara umum terdapat 2 (dua) sistem kelembagaan yang terkait dalam implementasi inovasi pengurangan kesenjangan wilayah, yaitu (1) kelembagaan dan tata kelola yang terkait dengan pihak inisiator inovasi, dalam hal ini terutama pemerintah daerah; dan (2) kelembagaan dan tata kelola terkait dengan masyarakat penerima manfaat atau kelompok sasaran program inovasi. Terkait dengan kelembagaan juga adalah pembagian peran antarpihak (stakeholder) yang terlibat dalam upaya pengurangan kesenjangan antarwilayah.

\subsubsection{Kelembagaan Inisiator}

Pengembangan inovasi daerah dalam pengurangan kesenjangan antarwilayah pada dasarnya melibatkan banyak pihak. Secara garis besar, pihak-pihak yang terlibat diantaranya adalah pemerintah (baik pemerintah pusat, pemerintah provinsi, maupun pemerintah kabupaten/kota); lembaga non-pemerintah, baik lembaga donor maupun lembaga swadaya masyarakat; pendamping/fasilitator masyarakat; konsultan; pihak swasta, masyarakat penerima manfaat, serta pihak lainnya yang terkait.

Ketidakjelasan penetapan peran masing-masing lembaga, termasuk tupoksi bagi organisasi perangkat daerah yang berwenang dalam pelaksanaan program inovasi akan menghambat proses inovasi yang berlangsung. Hal ini terjadi pada program inovasi One Village One Sister Company yang dikembangkan oleh Pemerintah Kabupaten Kulonprogo. Program ini pada dasarnya merupakan inovasi dengan melibatkan peran serta pengusaha untuk berpartispasi dalam pengembangan ekonomi di Kabupaten Kulonprogo. Masing-masing perusahaan diwajibkan melakukan pendampingan pada satu desa. Ketidakjelasan konsep yang akan dikembangkan dan OPD yang berwenang untuk mengelola dan mengkoordinir program mengakibatkan program tersebut tidak berlangsung lama.

Dukungan kebijakan dalam bentuk peraturan perundangundangan sangat diperlukan dalam pencapaian tujuan pembangunan 
daerah, termasuk tujuan implementasi inovasi pengurangan kesenjangan wilayah. Dalam konteks pengembangan inovasi daerah untuk pengurangan kesenjangan antar-wilayah, dukungan kebijakan memegang peranan yang penting, karena kebijakan menjadi landasan dan pelaksanaan inovasi yang efektif. Di dalam kebijakan diatur mengenai tujuan dan sasaran, organisasi pelaksana, peran dari berbagai pihak terkait, mekanisme perencanaan sampai dengan evaluasi, serta sistem pendanaan/penganggarannya. Dengan adanya kebijakan yang memiliki kekuatan hukum, pengembangan inovasi memiliki kepastian hukum bagi pemerintah daerah.

Untuk mendukung efektivitas pelaksanaan program dan jaminan legal basis pelaksanaan inovasi, maka penetapan peran lembaga di lingkungan pemerintah daerah beserta kewenangannya perlu ditetapkan dengan peraturan perundang-undangan. Umumnya penetapan peran lembaga di lingkungan pemerintah daerah dapat dilakukan melalui penetapan Peraturan Kepala Daerah.

Permasalahan kelembagaan juga dapat terkait dengan rentang kendali. Panjangnya rentang kendali antara perencana (inisiator) program inovasi dengan penerima manfaat dapat disiasati dengan pengembangan kelembagaan yang efektif. Pengembangan kelembagaan ini dilakukan melalui pembagian kewenangan dari pemilik (inisiator) program kepada pihak-pihak yang terkait, baik kepada pemerintahan yang lebih rendah maupun kepada pihak lainnya yang terkait. Pembagian kewenangan ini harus diimbangi dengan penetapan peran yang jelas.

\subsubsection{Kelembagaan Masyarakat Penerima Manfaat}

Pada tingkat penerima manfaat, kelembagaan diperlukan untuk menjamin distribusi program, pelaksanaan program, dan kemandirian masyarakat dapat terbentuk. Kelembagaan di tingkat penerima manfaat ini dikembangkan dalam bentuk community organizing $(\mathrm{CO})$. Pembentukan $\mathrm{CO}$ dapat menggunakan lembaga setempat yang sudah ada, maupun mengembangkan lembaga baru. Lembaga setempat yang sudah ada yang dapat digunakan diantaranya adalah Karang Taruna, Pemerintah Desa, PKK, Koperasi Desa, Dasa Wisma, Kelompok Petani, dan lain sebagainya. Penggunaan lembaga setempat yang sudah ada bergantung pada kebutuhan program inovasi yang dilaksanakan.

Program inovasi Pemberdayaan Ekonomi Masyarakat yang digagas oleh Kota Kupang sebagai contoh, menggunakan Lembaga Pemberdayaan Masyarakat (LPM) yang berada di bawah Pemerintah Desa untuk mengelola program di tingkat desa. LPM ini berfungsi sebagai CO dalam pengelolaan desa di masing-masing desa. Program inovasi Desa Mandiri Anggur Merah menggunakan koperasi desa sebagai CO di masing-masing desa. Meskipun sebagian desa belum memiliki koperasi, masyarakat membentuk koperasi baru sebagai CO sebagaimana yang dipersyaratkan dalam pelaksanaan program inovasi tersebut.

Apabila lembaga setempat yang sudah ada tidak dapat berperan sebagai CO dalam pengelolaan program, maka masyarakat dapat membentuk $\mathrm{CO}$ baru sesuai dengan kebutuhan. Hal yang perlu diperhatikan dalam pembentukan $\mathrm{CO}$ adalah keterwakilan kelompok 
masyarakat penerima manfaat. Perlu penjaminan bahwa kelompokkelompok minoritas dan rentan juga terwakili dalam keanggotaan CO.

Dalam pelaksanaan program inovasi, anggota CO harus dibekali dengan pengetahuan dan keterampilan yang memadai. Oleh karenanya pembentukan $\mathrm{CO}$ harus pula diimbangi dengan upaya peningkatan kapasitas CO. Pemerintah Daerah maupun lembaga non-pemerintah lain yang mengembangkan inovasi pengurangan kesenjangan wilayah dapat melengkapi program inovasinya dengan upaya peningkatan kapasitas anggota $\mathrm{CO}$. Hal ini untuk menjamin tingkat keberlanjutan dan kemandirian masyarakat dalam mengelola program.

Pengembangan kelembagaan yang kuat di tingkat masyarakat penerima juga dapat menjadi alat untuk proses sinkronisasi berbagai program yang diterima pada satu daerah/wilayah/ kelompok masyarakat yang sama. Di beberapa tempat dijumpai pada daerah/wilayah/ kelompok masyarakat yang sama menerima beberapa program yang diinisiasi oleh lembaga yang berbeda, baik program yang sifatnya sejenis maupun program yang sifatnya berbeda. Sebagai contoh, desa/kelurahan di Kota Kupang mendapatkan program Desa Mandiri Anggur Merah dari Pemerintah Provinsi Nusa Tenggara Timur dan program Pemberdayaan Ekonomi Masyarakat dari Pemerintah Kota Kupang. Kedua program relatif serupa dan merupakan program bidang ekonomi dengan pendekatan pemberian stimulan bagi pengembangan usaha ekonomi masyarakat. Perbedaan kedua program adalah pada mekanisme dan besaran dana yang diberikan. Agar tidak terjadi tumpang tindih dalam pemberian program, Pemerintah Desa/Kelurahan dan lembaga pendamping mengatur mekanisme lebih detail bagi masyarakat yang dapat menerima program agar tidak terjadi duplikasi.

\subsubsection{Peran Stakeholder}

Berdasarkan pengkajian terhadap sejumlah praktik baik dalam pengembangan inovasi daerah untuk pengurangan kesenjangan antarwilayah, berikut beberapa peran yang dilakukan oleh pemerintah daerah, antara lain:

\section{Penetapan Kebijakan}

Dalam rangka pelaksanaan inovasi pengurangan kesenjangan wilayah, pemerintah daerah berperan penting dalam penyiapan kebijakan yang menjadi landasan dan dasar bagi pelaksanaan kegiatan inovasi, baik yang dilakukan oleh pemerintah daerah sendiri maupun yang dilakukan oleh lembaga lain. Kebijakan yang ditetapkan dapat berupa penetapan inovasi beserta kelembagaan yang berwenang melaksanakan inovasi yang ditetapkan di lingkungan pemerintah daerah, pengembangan kebijakan dan strategi pengurangan kesenjangan wilayah, penetapan pedoman bagi lembaga nonpemerintah yang melakukan kegiatan pemberdayaan masyarakat dalam rangka pengurangan kesenjangan wilayah, dan lain sebagainya.

2. Penyedia dana/program pendukung

Pemerintah daerah dapat berperan sebagai penyedia dana dan/atau program pendukung yang diperlukan oleh masyarakat dalam rangka 
mengurangi kesenjangan wilayah. Selain sebagai penyedia dana langsung bagi pelaksanaan inovasi yang dilakukan oleh pemerintah daerah sendiri, pemerintah daerah juga dapat berperan sebagai penyedia program pendukung yang dapat diakses oleh masyarakat untuk mengurangi kesenjangan wilayahnya. Salah satu contoh program pendukung yang diberikan adalah pada Program Inovasi Satrya Emas yang dilakukan oleh Pemerintah kabupaten Pasuruan. Inovasi pengembangan usaha mikro dan kecil yang dikembangkan melalui program Satrya Emas mendapat bantuan melalui fasilitasi program yang tersebar di berbagai OPD terkait. Masyarakat penerima manfaat melalui fasilitasi pendamping dapat mengusulkan untuk mendapatkan program pemerintah yang terkait dengan bidang usahanya.

3. Pemberian bantuan teknis

Pemberian bantuan teknis pada dasarnya adalah pemberian pendampingan teknis bagi masyarakat penerima manfaat. Meskipun sebagian besar inovasi menggunakan tenaga pendamping (fasilitator) khusus untuk melakukan pendampingan teknis, namun sebagian program inovasi melakukan pendampingan teknis yang dilakukan sendiri oleh pemerintah daerah. Pendampingan teknis bisa dilakukan oleh OPD terkait yang memiliki kompetensi yang diperlukan. Sebagai contoh, pendampingan untuk petani bagi upaya peningkatan produksi pertanian dapat dilakukan oleh Pemerintah Daerah melalui Dinas Pertanian setempat maupun tenaga penyuluh pertanian.

4. Penyebaran informasi dan advokasi

Pemerintah daerah juga dapat berperan dalam memberikan informasi kepada masyarakat serta melakukan advokasi untuk perubahan perilaku ke arah yang diharapkan. Advokasi yang dilakukan oleh pemerintah daerah untuk mendorong perubahan perilaku masyarakat umumnya banyak dikembangkan pada inovasi di bidang kesehatan dan pendidikan. Sedang advokasi oleh pemerintah daerah di bidang ekonomi diantaranya adalah program inovasi Pengelolaan Pedagang Pasar Galendong (Kota Payakumbuh) merupakan salah satu contoh pengembangan advokasi oleh pemerintah daerah untuk penataan pasar dan pedagang kaki lima. Selain itu program inovasi Agam Menyemai yang digerakkan oleh pemerintah kabupaten Agam juga merupakan salah satu contoh peran pemerintah daerah untuk mendorong masyarakat mengembangkan lahan-lahan pekarangannya untuk pengembangan tanaman produktif.

5. Fasilitas Akses Pelayanan (dana, program, jejaring, pasar, dan lain sebagainya)

Selain bantuan dana dan bantuan teknis, pemerintah daerah juga dapat memfasilitasi kelompok sukarelawan maupun kelompok berbasis masyarakat yang bergerak di bidang pengurangan kesenjangan wilayah melalui penyediaan akses ke pelayanan yang dibutuhkan oleh masyarakat tetapi tidak disediakan oleh pemerintah, seperti akses kepada lembaga keuangan, akses kepada pasar, akses dalam membangun jejaring, dan lain sebagainya. 


\subsection{Keberlanjutan}

Tentunya seringkali terdapat beberapa hal yang menyebabkan suatu program harus berakhir, atau harus dimodifikasi, atau bahkan harus diganti. Baik itu karena sudah terinternalisasi program tersebut dalam keseharian masyarakat, sehingga masuk ke dalam proses kehidupan ekonomi, sosial, dan budaya tanpa membutuhkan pendamping secara intens; atau karena memang keterbatasan anggaran. Oleh karena itu, dibutuhkan exit strategy yang baik, dalam arti strategi untuk dapat menghentikan program dengan baik. Arti baik ini adalah masyarakat yang dibina akan tetap menjalan program tersebut. Pada dasarnya exit strategy yang baik bila program tersebut bisa berkelanjutan, dan berarti peluang-peluang di atas lah yang harus dijalankan. Exit strategy bukan berarti peran pendamping atau stakeholder lainnya lepas tangan begitu saja, namun perlu ada monitoring berkala dengan pendamping atau stakeholder pengelola yang lebih kepada advokasi saja, untuk memastikan tujuan pengurangan kesenjangan wilayah tetap berjalan.

\section{Kesimpulan dan Rekomendasi 4.1. Kesimpulan}

Kesenjangan antarwilayah di Indonesia disadari masih merupakan tantangan utama dalam pembangunan nasional. Kesenjangan antarwilayah tersebut juga terkait dengan upaya pemerataan pembangunan dan keadilan serta upaya untuk pengentasan kemiskinan. Dalam rangka mengurangi kesenjangan antarwilayah di Indonesia, pemerintah telah menetapkan target sebagaimana tercantum dalam RPJM Nasional 2014-2019, dimana kontribusi Kawasan Timur Indonesia terhadap PDB Nasional meningkat dari 20 \% (2014) menjadi sebesar minimal $22 \%$ (2019). Salah satu kebijakan yang dikembangkan untuk mencapai sasaran tersebut adalah mengembangkan dan memeratakan pembangunan daerah melalui peningkatan kinerja pusat-pusat pertumbuhan wilayah di Kalimantan, Sulawesi, Nusa Tenggara, Maluku dan Papua; menjamin pemenuhan pelayanan dasar di seluruh wilayah; mempercepat pembangunan daerah tertinggal dan kawasan perbatasan; serta mengoptimalkan pelaksanaan desentralisasi dan otonomi daerah.

Sejalan dengan era otonomi daerah dan desentralisasi, upaya pengurangan kesenjangan wilayah yang dilakukan oleh pemerintah daerah memiliki peran yang sangat penting. Hal ini didasarkan pemahaman bahwa kebijakan inovasi di tingkat daerah pada dasarnya akan menyesuaikan dengan potensi dan permasalahan daerah yang dihadapi, sumberdaya yang tersedia, SDM yang dimiliki, kreativitas daerah, daya saing serta kearifan lokal. Ketidaksesuaian program pemerintah dengan karakter dan kebutuhan daerah seringkali menjadikan program tidak berjalan efektif dalam mencapai tujuan. Selain itu, rentang kendali yang lebih pendek (manageable) penting bagi pengelolaan prakarsa pengurangan kesenjangan wilayah agar lebih efektif dan lebih mudah dipantau. Dengan adanya pembagian kewenangan tersebut, maka berbagai inisiatif dan aspirasi masyarakat untuk menggali potensi daerah akan lebih dapat digerakkan. Bila hal ini dapat dilakukan, maka proses pembangunan daerah secara keseluruhan akan dapat lebih ditingkatkan dan secara bersamaan ketimpangan pembangunan antar wilayah dapat pula dikurangi.

Selain upaya inovasi dan prakarsa pemerintah daerah terkait pengurangan kesenjangan wilayah, praktik di daerah menemukan sejumlah praktik inovasi terkait pengurangan kesenjangan wilayah yang dilakukan oleh sejumlah lembaga nonpemerintah, baik yang dilakukan oleh lembaga donor maupun lembaga swadaya masyarakat (LSM). Praktik inovasi tersebut meskipun dilaksanakan dalam skala yang lebih kecil, tetapi memberikan kontribusi yang cukup baik bagi peningkatan 
kesejahteraan masyarakat. Selain itu, lembaga non-pemerintah memiliki pengalaman dan pengetahuan yang lebih maju sehingga dapat menjadi pembanding (benchmark) untuk pelaksanaan program-program inovasi di pemerintah daerah.

Hal lain yang mengemuka adalah pentingnya pembagian peran antara Pemerintah Daerah dengan lembaga non-pemerintah serta pihak terkait (stakeholder) lain yang memiliki peran dalam upaya pengurangan kesenjangan wilayah. Distribusi peran yang baik akan meningkatkan efektivitas pelaksanaan inovasi program pengurangan kesenjangan wilayah sekaligus mengurangi beban pemerintah daerah.

Berdasarkan identifikasi program inovasi pemerintah daerah terkait pengurangan kesenjangan wilayah serta hasil kunjungan lapangan, diperoleh pembelajaran dari beberapa praktik baik (good practice) dalam proses pelaksanaan dan pengelolaan inovasi di daerah. Beberapa pembelajaran (lesson learned) yang diperoleh antara lain sebagai berikut:

\section{a. Bentuk dan pendekatan praktik inovasi daerah}

Inovasi daerah di bidang ekonomi paling banyak digunakan dalam pengurangan kesenjangan antarwilayah. Hal ini dikarenakan inovasi bidang ekonomi terkait langsung dengan upaya peningkatan pendapatan masyarakat. Pendekatan yang dilakukan relatif beragam, dari mulai pemberian stimulan, pendampingan teknis, pemberian akses pasar, advokasi, pengembangan klaster ekonomi, maupun pengembangan event/kegiatan untuk mendorong promosi. Dilihat dari pendekatan yang digunakan, sebagian besar praktik inovasi yang dilakukan daerah bersifat stimulan. Pemberian stimulan pada dasarnya adalah pemberian hibah baik berupa uang tunai maupun barang modal kepada masyarakat untuk mendorong kemampuan masyarakat secara lebih mandiri. Terkait dengan upaya keberlanjutan program inovasi ekonomi, hal yang perlu diperhatikan juga adalah bahwa upaya untuk peningkatan ekonomi masyarakat tidak cukup hanya dengan meningkatkan produktivitas, memberikan kesempatan berusaha yang sama, dan hanya memberikan suntikan modal sebagai stimulan, akan tetapi perlu dipastikan adanya kerjasama dan kemitraan dengan pihak lain untuk pengembangan usaha, termasuk kemitraan dengan pemasok bahan baku, pasar, lembaga keuangan, dan lain sebagainya

\section{b. Sinkronisasi dan koordinasi antarlembaga}

Pemerintah (terutama pemerintah pusat dan provinsi) memiliki beberapa program di berbagai sektor terkait upaya pengentasan kemiskinan dan pengurangan kesenjangan wilayah. Sejumlah program saling komplementer, sejumlah lainnya saling tumpang tindih (overlap). Untuk meningkatkan efektivitas pelaksanaan program serta efisiensi penganggaran, maka perlu dilakukan koordinasi dan sinkronisasi antar lembaga agar tidak terjadi tumpang tindih program dan pembiayaan. Dalam hal ini perlu ditetapkan institusi sebagai koordinator bagi pelaksanaan berbagai program pengentasan kemiskinan dan pengurangan kesenjangan wilayah. Koordinasi antar lembaga dapat dilakukan melalui sinkronisasi program prioritas dalam konteks Musrenbang.

\section{c. Penguatan kelembagaan}

Pengembangan program Inovasi pengurangan kesenjangan wilayah perlu didukung dengan sistem kelembagaan yang efektif, baik kelembagaan di pihak inisiator maupun kelembagaan di tingkat penerima manfaat.

\section{d. Ketepatan pemilihan program inovasi}


Pemilihan bentuk dan jenis inovasi yang dikembangkan di daerah perlu didasarkan pada pemahaman yang baik terhadap permasalahan yang dihadapi. Beberapa pertimbangan yang perlu dilakukan terkait pemilihan bentuk dan jenis inovasi yang akan dikembangkan antara lain adalah:

- Pemahaman yang baik terhadap permasalahan yang dihadapi serta karakteristik penerima manfaat.

- $\quad$ Rentang kendali terhadap perencanaan, pelaksanaan dan monitoring serta evaluasi program

- Pelibatan masyarakat/penerima manfaat dalam proses perencanaan, pelaksanaan, hingga monitoring dan evaluasi

- Peran pendamping/fasilitator yang kuat

\section{e. Pelibatan berbagai pihak}

Pengembangan program inovasi perlu melibatkan berbagai pihak, baik pemerintah daerah, masyarakat, maupun lembaga lain yang terkait. Pelibatan berbagai pihak tersebut meliputi juga proses membangun jejaring. Hal ini untuk memastikan program dapat dilaksanakan secara berkesinambungan. Pihak yang dapat terkait dalam pengembangan program inovasi antara lain adalah pemerintah (pemerintah pusat, pemerintah provinsi, dan pemerintah kabupaten/kota); tenaga pendamping masyarakat; lembaga swadaya masyarakat; lembaga donor; pihak swasta; dan lain sebagainya. Pada tahap perencanaan program inovasi, perlu terlebih dahulu dilakukan identifikasi terhadap pihak-pihak yang terlibat untuk memastikan jejaring yang akan dibangun. Pada tahap berikutnya masing-masing pihak perlu diidentifikasi pembagian peran agar masing-masing pihak dapat berperan dan berkontribusi secara lebih efektif dalam pelaksanaan program inovasi.

\section{f. Monitoring dan evaluasi}

Monitoring dan evaluasi perlu menjadi satu kesatuan dalam proses perencanaan program inovasi. Monitoring dan evaluasi perlu dilakukan secara reguler untuk memastikan ketercapaian tujuan pelaksanaan program. Monitoring diperlukan untuk memastikan proses inovasi berjalan sesuai rencana yang ditetapkan, sedang evaluasi diperlukan untuk menilai efektifitas pencapaian tujuan program inovasi. Hasil monitoring dan evaluasi digunakan untuk meningkatkan efektivitas pelaksanaan program inovasi.

\section{g. Exit Strategy}

Untuk menghindari ketergantungan masyarakat serta meningkatkan kemandirian, perlu disiapkan exit strategy pada setiap program inovasi. Exit strategy diperlukan untuk memastikan manfaat program dapat tetap berlanjut meskipun program inovasi selesai dilaksanakan. Exit Strategy perlu menjadi langkah akhir dalam pelaksanaan program inovasi untuk membangun kemandirian masyarakat serta menghindari ketergantungan serta memastikan keberlanjutan manfaat program bagi penerima manfaat.

\section{h. Pengembangan program inovasi yang lebih komprehensif dan terpadu}

Upaya pengurangan kesenjangan antarwilayah pada dasarnya tidak dapat hanya diselesaikan dari satu aspek saja, tetapi perlu melibatkan secara komprehensif dan terpadu dengan melibatkan berbagai sektor (ekonomi, pendidikan, kesehatan, infrastruktur, dsb). 


\section{i. Replikasi program inovasi}

Pada dasarnya praktik inovasi yang baik yang telah dilakukan di suatu daerah dapat direplikasi oleh daerah lainnya. Namun demikian, replikasi praktik inovasi yang baik tersebut tidak selalu dapat dilakukan secara seragam. Proses replikasi program inovasi perlu memperhatikan kondisi spesifik di masing-masing wilayah dan permasalahan riil yang dihadapi.

\subsection{Rekomendasi}

Berdasarkan hasil analisis, sintesis dan penetapan kesimpulan terhadap proses praktik inovasi di daerah terkait pengurangan kesenjangan antarwilayah, dapat dirumuskan beberapa hal sebagai berikut:

\section{a. Pembagian peran yang jelas di antara stakeholder}

Berdasarkan analisis, sintesis dan kesimpulan, salah satu penyebab kurang efektifnya pelaksanaan program inovasi pengurangan kesenjangan antarwilayah di daerah adalah rentang kendali yang cukup panjang sehingga efektivitas pencapaian tujuan serta proses pemantauan dan evaluasi pelaksanaan menjadi kurang efektif. Salah satu upaya untuk mengatasi hal ini adalah pengembangan manajemen kelembagaan melalui pembagian peran antar pihak.

\section{b. Pengembangan Kelembagaan di tingkat masyarakat}

Selain kelembagaan di tingkat inisiator program inovasi, kelembagaan di tingkat masyarakat penerima manfaat memegang peranan penting dalam mendukung efektivitas pencapaian tujuan program inovasi. Salah satu permasalahan yang dihadapi adalah kebutuhan untuk sinkronisasi dan pendistribusian secara adil dan efektif terhadap berbagai program yang didapat dari berbagai lembaga pada satu daerah/kelompok masyarakat yang sama. Kelembagaan yang kuat di tingkat masyarakat dapat meningkatkan efektivitas pendistribusian berbagai program tersebut agar saling komplementer dan tidak saling tumpang tindih. Selain itu, kelembagaan yang baik di tingkat masyarakat juga dapat menjamin kemandirian dan keberlanjutan program di masa datang. Untuk itu diperlukan upaya peningkatan kapasitas bagi kelembagaan di tingkat masyarakat.

\section{c. Fasilitator (pendamping) yang kuat}

Dalam hampir semua program inovasi, kebutuhan tenaga pendamping (fasilitator) memegang peranan yang signifikan dalam menjamin efektivitas pencapaian tujuan. Tugas utama pendamping adalah memfasilitasi proses belajar atau refleksi dan menjadi mediator untuk penguatan kemitraan masyarakat dengan pihak lain. Persoalan penyediaan tenaga pendamping dengan kualifikasi yang baik seringkali menjadi kendala bagi pengembangan program. Penentuan bagi pendamping masyarakat yang efektif seringkali masih menjadi persoalan. Pengalaman empiris dari pelaksanaan berbagai program pemberdayaan masyarakat melalui pendamping dari luar, seringkali mengakibatkan biaya transaksi bantuan modal menjadi sangat mahal. Selain kebutuhan pemberian upah bagi tenaga pendamping, kebutuhan biaya pelatihan bagi tenaga pendamping juga relatif tidak kecil.

\section{d. Pengembangan inovasi secara komprehensif dan integratif}

Permasalahan pengurangan kesenjangan antarwilayah pada dasarnya tidak sekedar permasalahan peningkatan pendapatan perkapita, tetapi meliputi berbagai aspek yang berpengaruh terhadap pendapatan perkapita, seperti 
peningkatan kualitas sumberdaya manusia, peningkatan mobilitas dan aksesibilitas, dan lain sebagainya. Oleh karenanya, inovasi untuk pengurangan kesenjangan antarwilayah perlu dikembangkan secara komprehensif dan integratif dari berbagai bidang. Upaya inovasi pengembangan ekonomi perlu juga diimbangi dengan peningkatan pendidikan, peningkatan kesehatan masyarakat, serta peningkatan infrastruktur wilayah.

\section{e. Penyediaan akses permodalan}

Dalam berbagai program pemberian stimulan berupa modal usaha, pada satu sisi pemberian hibah maupun dana bergilir berupa modal usaha tidak berjalan efektif dan mengakibatkan ketergantungan. Praktik inovasi bidang ekonomi melalui aspek permodalan yang perlu dicermati adalah: (i) bagaimana pemberian bantuan modal tidak menimbulkan ketergantungan masyarakat terhadap pemberi bantuan; (ii) bagaimana pemecahan aspek modal dapat dilakukan melalui penciptaan sistem yang kondusif bagi usaha mikro, kecil dan menengah untuk mendapatkan akses terhadap lembaga keuangan formal; serta (iii) bagaimana skema penggunaan atau kebijakan pengalokasian modal tidak terjebak pada perekonomian subsisten.

\section{f. Replikasi program inovasi di daerah.}

Replikasi program merupakan tahapan dalam upaya menggunakan contoh program baik dalam pengurangan kesenjangan. Upaya ini harus melalui tahapan yang melibatkan berbagai aspek dimulai analisis kesesuaian program dengan kondisi wilayah, penyiapan kelembagaan (organisasi, SDM, sampai dengan pendanaan) keterlibatan stakeholder. Tahapan-tahapan tersebut adalah sebagai berikut :

1. Pemahaman terhadap persoalan

Permasalahan yang dihadapi masyarakat bersifat spesifik, baik dari aspek lokasi maupun dari aspek permasalahannya. Oleh karena itu, maka pengembangan program inovasi dilakukan tidak secara generik, melainkan menyesuaikan dengan permasalahan yang bersifat spesifik.

\section{Perencanaan}

Setelah persoalan dan kondisi yang dihadapi diidentifikasi secara baik, Pemerintah Daerah dapat menetapkan jenis dan bentuk inovasi yang akan dikembangkan. Pada tahapan ini dilakukan proses penyiapan perencanaan program yang akan dikembangkan. Tahapan ini dilakukan dengan menetapkan kegiatan-kegiatan yang akan dilakukan, sumber daya yang dibutuhkan (pembiayaan, fisik, manusia, kearifan lokal, dll), waktu pelaksanaan, target, pengelola program, dan stakeholder yang terlibat

3. Implementasi

Pelaksanaan dari program harus dapat diterapkan sesuai dengan rencana, dengan melibatkan stakeholder dan pendamping sesuai dengan kebutuhan. Dalam proses implementasi, peran pendamping dan kelembagaan di tingkat penerima manfaat memegang peranan yang besar untuk memastikan efektivitas pencapaian tujuan. Oleh karenanya upaya peningkatan kapasitas bagi pendamping maupun lembaga penerima manfaat perlu menjadi perhatian.

4. Monitoring dan Evaluasi

Tingkat pencapaian program harus dapat diukur secara berkala, dinilai keberlanjutan dan dampaknya, untuk selanjutnya menjadi bahan 
masukan perencanaan berikutnya. Proses monitoring dan evaluasi wajib dilakukan untuk memberikan masukan bagi perbaikan proses perencanaan dan implementasi program. Pelibatan berbagai pihak (baik pemerintah daerah, pendamping, pihak ketiga, maupun masyarakat) dapat meningkatkan efektivitas hasil monitoring dan evaluasi yang dilakukan

\section{Daftar Pustaka}

Bappenas, 2012. Analisis Kesenjangan Antar Wilayah 2012.

Boslaugh, Sarah. (2007). Secondary Data Sources for Health: A Practical Guide. Cambridge: Cambridge University Press. [Excerpt published online: "I An Introduction to Secondary Data Analysis"]

Direktorat Penanggulangan Kemiskinan - Bappenas. 2011. Evaluasi Karakteristik dan Program Penanggulangan Kemiskinan di Daerah. Laporan Akhir.

Drucker, Peter., 1986. Innovation and Entrepreneurship. Gramedia Pustaka Utama, Jakarta.

Dwiyanto, Agus, 2006. Reformasi Birokrasi Publik di Indonesia. Gajah Mada University Pressišp?

Everette M.Rogers. 1983 . Diffusion of Innovation. New York: The Free Press A Division of Macmilan Publishing Co.Inc

Fraenkel Jack, R. and Wallen Norman, E. (1993) How to design and evaluate research in education. 2nd Edition, McGraw-Hill Inc., New York.

Gulick, L. and Urwick, L. (1937) Papers on the Science of Administration. Institute of Public Administration, New York.

Habanik, Jozef, Peter Hostak dan Jan Kutik. 2013. Economic and Social Disparity Development Within Regional Development of The Slovak Republik. Economic and Development Journal. Vol. 18 No. 3.

Jha, S.N. \& Marthur, P.C. 1999. Decentralization and Local Politics: Reading in Indian Government and Politics-2. New Delhi London: Sage Publications.

Marczyk, G., DeMatteo, D., \& Festinger, D. (2005). Essentials of Research Design and Methodology. New York, NY: John Wiley \& Sons, Inc.

Muluk, M.R Khairul. 2007. Desentralisasi dan Pemerintahan Daerah. Malang: Bayu media Publishing.

Pusat Kajian Kinerja Otonomi Daerah - Lembaga Administrasi Negara, 2010. Model Community Developoment di Daerah.

Sinambela, Dr. Lijan Poltak, M.M., M.Pd, 2006. Reformasi Pelayanan Publik, Teori,

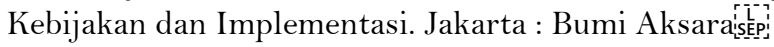

Sumarto, Hetifah Sj, 2003. Inovasi, Partisipasi dan Good Governance, 20 Prakarsa inovatif dan Partisipatif di Indonesia. Jakarta : Yayasan Obor Indonesia

Sjafrizal. 2012. Ekonomi Wilayah dan Perkotaan. Jakarta: PT Rajagrafindo Persada

Taylor, Steve J. Robert Bogdan, dan Marjorie DeVault. 2015. Introduction to Qualitative Research Methods: A Guidebook and Resources, 4th Edition. New York: John Wiley and Sons. 
Villaverde, Jose dan Maza, Adolfo. 2011. Regional Disparities in the UE: Are They Robust to the Use of Different Measures and Indicators? Swediesh Institute for European Policy Study.

Undang undang Nomor 23 Tahun 2014 tentang Pemerintahan Daerah

Undang-undang Nomor 18 Tahun 2002 tentang Sistem Nasional Penelitian, Pengembangan, dan Penerapan Ilmu Pengetahuan dan Teknologi.

Peraturan Bersama Menteri Negara Riset dan Teknologi Nomor 03 Tahun 2012 serta Menteri Dalam Negeri Nomor 36 Tahun 2012 tentang P enguatan Sistem Inovasi Daerah

Peraturan Pemerintah Nomor 2 Tahun 2015 tentang Rencana Pembangunan Jangka Menengah Nasional Tahun 2014-2019 